\title{
Towards a Concept of Parental Authority in Adolescence
}

MetKa KuHaR $^{* 1}$ AND Herwig Reiter ${ }^{2}$

$\approx$ The notion of authority is common in the literature on parent-child relationships. However, the notion of 'parental authority' remains largely unspecified. The present article first critically reviews conceptualisations of parental authority in selected developmental-psychological approaches. We find the absence of an explicit and integrated theoretical and empirical conceptualisation of parental authority, as well as a certain lack of consistency in the application of the concept. Against the background of this review, we suggest initial steps towards a concept of parental authority as relational, dynamic and co-constituted in the sense of a joint product and outcome of family relationships.

Keywords: Parental authority; Control; Power; Recognition; Parentchild relationship; Adolescence 


\section{O konceptu starševske avtoritete $\mathrm{v}$ adolescenci}

Metka Kuhar * AND Herwig Reiter

$\propto$ Ideja avtoritete je v literaturi o odnosih med starši in otroki pogosto prisotna, a pojem »starševska avtoriteta« po večini ostaja neopredeljen. V članku najprej kritično pregledamo različne konceptualizacije starševske avtoritete v izbranih razvojnopsiholoških pristopih. Pri tem pokažemo na primanjkljaj jasne in celovite teoretične in empirične konceptualizacije tega pojma pa tudi na pomanjkanje doslednosti pri njegovi uporabi. $\mathrm{Na}$ podlagi pregleda predlagamo nekaj mogočih zasnov za konceptualizacijo starševske avtoritete kot relacijske, dinamične in sodoločene v pomenu skupnega rezultata družinskih odnosov.

Ključne besede: starševska avtoriteta; nadzor; moč; priznavanje; odnos med starši in otroki; adolescenca 


\section{Introduction}

There are at least two reasons for the importance of the question of parental authority today. On the one hand, both parents and children increasingly adhere to democratic ideals and negotiated communication within the family context (du Bois-Reymond, Büchner, \& Krüger, 1993; du Bois-Reymond, Poel, \& Ravesloot, 1998; Solomon, Warin, Langford, \& Lewis, 2002). This is, on the other hand, contrasted by the persistence of more indirect, covert and invisible power asymmetries between parents and children (Brannen, Dodd, Oakley, \& Storey 1994; Solomon et al., 2002). As a consequence of this contradiction, parents may, for instance, wonder in what manner and how often authority should be 'used' in parenting practices (Schneewind, 1999). On the whole, the picture is ambiguous (cf. Ashbourne, 2009). Parents' formal status alone no longer guarantees that their suggestions are followed; they are no longer taken for granted as leading figures by their children. Instead, parents have to defend and often reclaim their authority anew by, for instance, offering principled justifications of their decisions and guidelines (Giddens, 1992).

In general terms, authority, like power, is an essentially relational category. Authority involves the relationship between at least two parties that "exists when one individual, prompted by his or her circumstances, does as indicated by another individual what he or she would not do in the absence of such indication" (Zambrano, 2001, p. 978). Unlike power, which can involve the overcoming of explicit resistance and which is equally relevant to family, parenting and communication research (e.g., Blood \& Wolfe, 1960; Cromwell \& Olson, 1975; Dunbar, 2004; Hallenbeck, 1966; Rollins \& Bahr, 1976; Safilios-Rothschild, 1970; Scanzoni, 1979), authority requires legitimacy (Ule, 1977; Kroflič, 1997). It is "linked to the idea of legitimization, the right to make particular decisions, and to command obedience" (Perelberg, 1990; emphasis added). In contrast to power, authority is stabilised and 'institutionalised' by legitimacy, which is "what keeps the relationship from breaking down", as Zambrano (2001, p. 978) notes.

In the present article, we seek to develop a more comprehensive concept of parental authority on the basis of a critical review of selected parenting paradigms that offer valuable starting points to understanding the dimensions of the phenomenon. We have chosen influential contemporary frameworks of developmental psychology, in which notions of parental authority are rather explicitly relevant in negotiations between parents and children: parenting style theory, the parental control paradigm, social domain theory, and research on 
power and authority in parent-adolescent relationships. ${ }^{3}$ These approaches have been chosen for two main reasons. First, they were not developed in isolation from each other, but rather in a process of mutual exchange of key proponents. Second, with this selection we narrow the focus of our exploration to the life course phase of adolescence, rather than childhood or young adulthood. ${ }^{4} \mathrm{We}$ believe that adolescence is particularly suitable for illustrating the basic paradoxes of parental authority, especially its contribution to the gradual increase in autonomy of action and independence of thinking.

The paper begins with a review of notions of parental authority within the selected influential approaches from developmental psychology, and a search for conceptualisations. In order to facilitate the comparison, and to make it feasible within the framework of the present article, we restrict the discussion to a few key aspects and questions. We look at how authority is legitimised, and at the manner of its assertion in these approaches that is related to the development and texture of rules and their implementation. Questions concerning the status of aspects such as parental control and sanctions, as well as dialogic negotiation or children's participation, are relevant here. The consideration of the child's perspective is crucial for an assessment of the dimension of legitimacy in these approaches. The possible transformation of parental authority as the adolescent matures is associated with this. Other aspects that can shape parental authority include the overall quality of the relationship between parents and children, the cultural and ethnic background, the child's gender and temperament, or special needs. Building on the review of these approaches, we suggest and outline a conceptual proposition of parental authority that considers its essentially relational and dynamic character: parental authority is constantly communicatively constructed and reproduced in an intergenerational exchange process. The paper concludes with a few suggestions about how research could benefit from an elaborated conceptualisation and more consistent use of the concept of parental authority.

\section{Reviewing notions of parental authority}

\section{The parenting style approach}

With its central concept of "parental authority styles" (Baumrind, 1966, 1967, 1971, 1991, 2012; Baumrid, Larzelere, \& Owens, 2010), this approach raises

3 We have had to omit others, such as Hoffman's information processing theory with its typology of parental discipline measures (e.g., Hoffman, 1970, 1983), because the significance of parental authority is to a large extent only implicit in this case.

4 The parenting style paradigm was initially developed with preschoolers (Baumrind, 1966, 1967, 1971), but in more recent works parenting of adolescents has been examined (Baumrid, 1991; Baumrind et al., 2010). 
the expectation of an elaborate conceptualisation of parental authority. However, the term refers rather vaguely to the notion of expertness, associating authority with a person's expert power, as recognised by a subordinate person. In an earlier publication, Baumrind (1966, p. 887) describes an "authority" as "a person whose expertness befits him to designate a behavioral alternative for another where the alternatives are perceived by both". One of the reasons for this cautious definition could be related to Baumrind's observation that the use of the authority concept involves the risk of being associated in a prejudiced way with the renowned authoritarian-personality syndrome (Adorno, FrenkelBrunswik, Levinson, \& Sanford, 1950; Lewin, Lippitt, \& White, 1939). She later explains the concept's unpopularity with the significant influence of the educational philosophy of permissive and child-centred pedagogical attitudes and approaches (Baumrind, 1996).

Notwithstanding the unspecific definition of authority in this approach, some of its aspects become evident from the three original basic parenting styles that are distinguished: authoritarian, authoritative, and permissive (Baumrind, 1967, 1971; Buri, 1991). These styles represent configurations of several interrelated parenting aspects: parental control and disciplinary efforts; nurturing skills; communication style; parental consideration of demands depending on the child's level of maturity; and their general supportiveness and emotional attunement (Baumrind, 1971).

Baumrind's original contribution was revised by Maccoby and Martin (1983), who define parenting styles by distinguishing two underlying dimensions: parental demandingness (i.e., control, supervision, maturity demands) and parental responsiveness (i.e., warmth, acceptance, involvement). The interaction between the two dimensions has produced four, not three, distinct parenting styles. In her later work, Baumrind $(1989,1991)$ picked up on these two orthogonal factors (called by her "control" and "warmth"), and even more styles have been identified in subjects in her longitudinal study: disengaged in addition to the original three, as well as three other styles (directive, goodenough, democratic). In a recent contribution, the patterns were even further and more complexly differentiated by adding the intrusiveness/psychological control dimension (Baumrind et al., 2010). We refer here only to the original three parenting styles distinguished by Baumrind (1967, 1971).

The definitions of the main parenting styles emphasise different ways of using power, control and discipline. In the case of authoritarian parenting, coercive, unilateral forms of power assertion are applied in order to "maintain family hierarchy in which children are subordinate" (Baumrind et al., 2010, p. 184). Permissive parenting is characterised by parental reluctance to assert 
confrontive power, at the risk of failing to provide authority, order, and regimen where it may be necessary (Baumrind et al., 2010, p. 184). These two parenting styles are criticised for their idealisation of (positive or negative) control, and are considered inappropriate compared to the third approach of authoritative parenting, which supports autonomy and responsible agency among children (Baumrind, 2005). The authoritative ideal combines high behavioural control and confrontive (i.e., firm, direct, forceful and consistent) discipline with opportunities for reciprocal communication, 'moderately open' negotiation and autonomous choice (especially during adolescence); authoritative parents also avoid verbal hostility and psychological control (Baumrind et al., 2010; Baumrind, 2012). This parenting style emphasises the importance of parental demands being just, and parental authority being reasoned and legitimate; if this is not achieved, the child may resist and defy parental authority, or even distance him/herself emotionally (Baumrind, 2005; Baumrind et al., 2010).

Authoritative parenting does not completely abandon the ideas of parental authority, power and control. However, the relatively high level of parental control originally promoted in this parenting style (e.g., Baumrind, 1983) has been criticised (Grolnick, 2003). In the meantime, the emphasis on (the short-term goal of) the maintenance of family order through parental authority (Baumrind, 1991) has shifted to the long-term project of promoting sustainable initiative, self-determination, social responsibility and moral competence (Baumrind, 2005; Baumrind et al., 2010).

This parenting style approach suggests that parents (should) argue their demands increasingly thoroughly as the child's maturity progresses (Baumrind, 1996). Toddlerhood and especially adolescence are conceived as periods during which children contest and subvert parental authority in order to broaden their personal freedom (Baumrind et al., 2010). Parental authority should be transformed as the child gets older (Baumrind, 2012). Together with the ideal of balancing parental demands for behavioural compliance (which may require power-assertive confrontation) with opportunities for negotiation, fair reasoning and increasing autonomy, this age sensitivity testifies to the approach's consideration of the child's perspective. The age-sensitivity of this approach is complemented by studies differentiating the effects of authority in various cultural and social contexts. Findings are ambiguous: for instance, proponents of the cultural equivalence model claim that the effects of authority are consistent across cultures (e.g., Lamborn \& Felbab, 2003; Sorkhabi, 2005; Steinberg et al., 1991, 1994), while others claim that context mediates the effects (e.g., Florsheim, Tolan, \& Gorman-Smith, 1996; Mason, Cauce, Gonzales, \& Hiraga, 1996; Mandara, 2006). Nevertheless, while relations between parental regulation and 
certain developmental outcomes (e.g., problem behaviour, competence) have been studied extensively (e.g., Baumrind, 1991; Baumrind et al., 2010), an indepth discussion of how power is actually negotiated between children and parents, and how parental authority is legitimated from the perspective of the child, is missing (cf. Maccoby, 2007).

\section{The parental control paradigm}

Again in the second approach, which we will call the 'parental control paradigm, authority is obviously important but conceptually underdeveloped. Numerous contributions deal extensively with the conceptualisation (and operationalisation) of parental control and autonomy support, as well as associations between these constructs (e.g., Barber, 1996; Barber, Olsen, \& Shagle, 1994; Grolnick \& Pomerantz, 2009; Schaefer, 1965; Soenens \& Beyers, 2012; Steinberg, 1990). However, their connection to the concept of authority is not established. In fact, the term is hardly used, although one would expect it from the many ongoing conceptual debates, especially with regard to the notion of control (Soenens \& Beyens, 2012). One of the most important distinctions of this approach is the difference between behaviour control and psychological control. Behaviour control typically includes parental regulating strategies, such as setting expectations (Barber, 1996), monitoring activities outside home (Barber, 1996; Gray \& Steinberg, 1999; Stattin \& Kerr, 200o), limit-setting (Barber, Maughan, \& Olsen, 2005), or the parents' involvement in making decisions for children (Fletcher, Steinberg, \& Williams-Wheeler, 2004). Psychological control, on the other hand, usually refers to intrusive and manipulative activities of parents, such as guilt-induction, shaming or love-withdrawal (Barber, 1996; Schaefer, 1965); unlike behaviour control, this it is associated with negative outcomes for youth (e.g., Barber \& Hamon, 2002; Conger, Conger, \& Scaramella, 1997; Galambos, Barker, \& Almeida, 2003; Gray \& Steinberg, 1999).

Recent contributions to the debate challenge this distinction. For instance, Grolnick and Pomerantz (2009) suggest replacing the two dimensions of behavioural and psychological parental control. Instead, the notion of 'structure' (or 'guidance'), which refers to parental practices dealing with discipline and the setting of rules and expectations, should be used together with the notion of 'control' referring to parental pressure, intrusiveness or dominance. The original outline of this reconceptualisation does not clarify the parental status as figures of authority and the manner of its assertion in either of the two dimensions of structure or control. However, in their response to critics such as Conger (2009) or Grusec (2009), who point to various problematic aspects of their contribution, Pomerantz and Grolnick (2009) maintain that, in the end, 
parents are in charge in both structure and control. They acknowledge that the existence of structure in their model "entails parents as the ultimate authority" - parents define the degree of the child's autonomy - but "the manner of implementing structure by authority figures determines the outcome, which may either be autonomy supporting or controlling" (Pomerantz \& Grolnick, 2009, p. 177; emphasis added).

Elsewhere, authority is explicitly counted among the six components of structure that are "relevant to children's motivation and adjustment" (Farkas \& Grolnick, 2008 quoted in Grolnick, 2009, p. 167), with the others being: (1) clear and consistent rules, guidelines and expectations; (2) opportunities to meet or exceed expectations; (3) predictability; (4) informational feedback; and (5) provision of rationales. Nevertheless, exactly how this way of exercising parental rules/demands is related to parents as authority figures remains unclear. Furthermore, the manner of asserting rules/demands is not distinguished from their scope.

In this context, Steinberg's (2005) challenging stance on psychological control is relevant. He suggests that it is not clear whether psychological control refers to certain ways of parental authority assertion in the sense of styles, or rather to the (extent of) issues (social domains) over which parents attempt to exercise their authority, in the sense of substance. In line with this distinction of style and substance, we would suggest that the key difference between structuring and controlling, or between behavioural vs. psychological control, seems to reflect the distinction between a more deliberative and overt way of parental authority assertion in contrast to a more coercive and covert one. Only the former is open to the child's participation.

Although studies following this approach empirically observe adolescents' subjective experiences of control together with parental support of the child's autonomy (which is considered relevant especially vis-à-vis parental psychological control), there is - with the exception of the theoretical mention of the provision of rationales in Grolnick, 2009 - no emphasis on parent-child negotiation. In the end, the parental control approach essentially operates on the basis of a non-interactionist concept of authority, in which the child's role is only implicit.

\section{The social domains approach}

The social domains approach addresses the development of children's social knowledge within the three distinct conceptual domains of the moral, the conventional and the psychological (Smetana, 2011). Furthermore, it analyses the coordination of parental demands and regulations, on the one hand, and 
children's zones of autonomy and self-determination in various contexts and situations, on the other. The focus is on the scope and content of parental rules and the reasoning behind them, as well as on the child's perception of the legitimacy of parental authority and the obligation to obey. The key advantage of this approach lies in the fact that it considers the dialogic background of parental authority within the complexity of the parent-child relationship.

This approach employs parental authority as a key term without explicit definition. Sometimes the term is even used as a synonym for "control over the child's behaviour", as, for example, in Cumsille, Darling, Flaherty, and Martinez (2009, p. 418): "As adolescents move from childhood dependence to adult autonomy, they claim ownership of their decision-making processes. One aspect of this transformation is a change in the aspects of adolescents' lives that they and their parents consider to be legitimately within the sphere of parent control or authority" (emphasis added).

The implicit key point of 'legitimacy of parental authority' refers to the extent to which the parental regulation of the respective conceptual domains is perceived as legitimate by both parents and adolescents. Therefore, parental authority appears to be functionally equated with being 'the vehicle' for asserting the parental will. ${ }^{5}$ Despite the child's involvement, the locus of rule-setting power is on the parental side. This is regarded as "a natural or appropriate extension of their role as parents" (Darling, Cumsille, \& Martinez, 2007, p. 299); or "parents typically decide how much, and what types of, autonomy to grant to their children", as Daddis and Smetana (2005) write. However, the role of children in this approach is not passive; they are recognised as the party that has to legitimise authority, and that is eager to expand its own autonomy.

Findings from research distinguishing gender, cultural, ethnic, and socioeconomic features indicate that parents of preadolescents and younger adolescents tend to consider all sorts of issues as depending on parental decisionmaking (e.g., Smetana, 1995; Yau \& Smetana, 1996). As adolescents grow up, parents generally reduce their (behavioural) control only with regard to personal (e.g., the use of free time or watching videos) and friendship issues. Moral, conventional and prudential (e.g., smoking, drinking, and drug use) issues, on the other hand, tend to remain under parental control. However, examples of considerations in the moral domain highlight the importance of children's experiences and inductive argumentation for recognition of the legitimacy of (moral) norms; therefore, unlike the conventional domain, (continuous) adult

5 Some other approaches similarly equate parental authority with the locus of decision-making power being on the side of parents (as in Bosma, Jackson, Zijsling et al., 1996; Dornbusch, Ritter, Mont-Reynaud, \& Chen, 1990). 
authority (after the child's age of 4 or 5 ) is not required to legitimise moral norms (Nucci, 2001). Progressive flexibilisation of rules and of children's duties is thought to lead to more self-regulation and autonomy during the later phase of adolescence. Studies indicate that continued parental involvement in the child's choices and joint decision making in early and middle adolescence are optimal for healthy adjustment (Smetana, 2011). By the end of adolescence, previously asymmetrical relationships between parents and their children are supposed to become more equal and reciprocal (Smetana, 1995; Smetana, Crean, \& Campione-Barr, 2005).

In addition to varying depending on the respective domain and the specific age, the boundaries of parental authority in adolescence vary according to gender (of both child and parent), social contexts, social classes, and cultures (for an overview, see Smetana, 2011). Furthermore, many interpersonal and intrapersonal factors are relevant, including: "parents' beliefs about the appropriate timing for granting autonomy, their assessment of their adolescent's abilities and competence to assume more privileges and responsibilities, their parenting styles, and their appraisal of the environmental risks of allowing their teens more freedom" (Smetana et al., 2005, p. 42); the quality of the parent-child relationship; the (mis)match of temperaments (Smetana, 2011, p. 177); and even parental mood (Smetana, 2011, p. 206). The perceived legitimacy of parental authority and the adolescent's obligation to obey (also in the case of disagreement) are related to the level of the adolescents' general agreement with their parents and global beliefs about their obligation to obey (Darling et al., 2007); the coherence of parental rules in combination with their strict enforcement (i.e., level of parental supportiveness and monitoring); the presence/absence of the child's problem behaviour; and the adolescent's self-efficacy level (Cumsille et al., 2009). These findings indicate the complexity and negotiation-based preconditions of being recognised as an authority.

This approach considers the supportive attitude of parents towards the child's autonomy as indispensable for the development of the child's competences (Nucci \& Smetana, 1996; Smetana \& Chuang, 2001). Open, reciprocal communication and negotiations are described as universally benefiting the child's development; coercion is considered as developmentally harmful. According to this approach, the boundaries of parental authority are transformed by the parents' self-limitation, as well as by the (continuous) negotiation of their capacity to regulate different aspects of their children's lives and their emerging desires for more autonomy and personal freedom (Smetana, 2011). Already during early childhood - and, with regard to more complex issues, during adolescence - children often disagree with parents about which issues (especially prudential and 
contextually conventional) fall under legitimate parental regulation and which are personal (Smetana, 2011). Adolescents typically demand autonomy earlier than their parents are ready to grant it (Smetana, 1988). These differences in perception can lead to parent-child conflicts; however, they are explicitly seen as an important opportunity to renegotiate - and gradually and subtly shift - the boundaries of parental authority (Smetana, 1989; Smetana et al., 1991).

In other words, the process involves typical roles: parents are presented as constantly balancing the pros and cons of asserting their authority, or of granting children autonomy with regard to specific issues, while children are presented as accepting or rejecting parental authority and constantly pushing for greater personal discretion and choice. Conceptually, children are the weaker party; they do, however, have the option of avoiding conflict - by means of non-disclosure, for instance - in cases when they believe they are not obliged to obey parental restrictions (Smetana, Metzger, Gettman, \& Campione-Barr, 2006; Yau, Tasopoulos-Chan, \& Smetana, 2009). Moreover, resistance and challenges to parental authority are recognised as normative, adaptive and in the service of attaining greater autonomy. When parental authority is generally recognised as supportive, the child's resistance to the particular parental rules will only slow down the process of the adolescent's emancipation. However, some forms of adolescent self-assertion that entail defiance and rebellion are labelled as destructive or dysfunctional (Smetana, 2011).

\section{The attributive theory of authority}

A fourth approach considered is one we will call the 'attributive theory of authority'. Rather than being an established theory, this approach is represented by a group of researchers who explicitly consider parental authority as an important theoretical and empirical dimension when exploring various aspects of parenting and their outcomes in children (e.g., Bush et al., 2004; Peterson, 1986; Peterson \& Hann, 1999; Peterson, Bush, \& Supple, 1999; Peterson, Rollins, \& Thomas, 1985; Peterson, Bush, Wilson, \& Hennon, 2005). Some of these researchers have even suggested using the notion of authority regularly in addition to established dimensions such as parental support/connection, parental monitoring and coercive parenting (Bush, Peterson, Cobas, \& Supple, 2002). This would lead to a greater generalisability of results, and especially to a more accurate assessment of the potential universality of parental socialisation processes.

Parental authority has been defined as the "subjective perception that parents have abilities or competencies to exercise influence but may or may not actually enact this potential" (Peterson \& Hann, 1999, p. 338). Importantly for our discussion, this definition explicitly includes the children's perspective: parental 
authority refers to the features that young people attribute to their parents' influence in the sense of perceived abilities, resources, legitimacy, credibility, etc.

Furthermore, this approach emphasises the importance of children's developing competences, and how they influence the power dynamics of parentchild relationships during adolescence (Peterson \& Hann, 1999; Peterson et al., 1999). This approach applies a double perspective: while parental authority is investigated through the perceptions of teenagers, the authority of adolescents is observed from mothers' and fathers' viewpoints. The acknowledgement of adolescent authority in addition to parental authority has the advantage of enabling the investigation of parent-child relationships as a process of mutual perceptions of each other's abilities to influence situations and each other's re/ actions. At the same time, it is possible to conceptualise the exchange and confrontation of authority such that it develops towards greater mutuality as the child grows older.

Peterson et al. (2005) distinguish parental authority analytically from parental socialisation behaviours and emotional attachment relationships to children. They underline the importance of the influence of the evolving history of relationships between parents and adolescents on the child's perception of parents as authority. Children learn to assess the capability of parents and turn it into anticipation. More than gender or age, this approach emphasises the role of culture: findings suggest that authority is a particularly important dimension of parental behaviour in collectivist cultures, such as Chinese, Mexican, etc. (Bush et al., 2002, 2004).

Another useful contribution of this approach to the debate is the distinction of parental authority types according to social bases of authority (Peterson \& Hann, 1999; Peterson et al., 1999), which draws on French and Raven's (1959) classification of different forms of power. Peterson and Hann (1999, p. 338) distinguish between parental reward, coercive, legitimate, expert and referent forms of authority. Parental reward authority is defined as the perceived ability to provide gratifications as a means of influencing the child's behaviour. Parental coercive authority refers to the parents' perceived ability to bring about punishment or adverse consequences. Legitimate authority is defined as the perceived parental 'right' to exercise influence or to control circumstances based on social norms. Expert authority refers to the adolescents' perception of their parents as knowledgeable and reliable sources of information. Finally, referent authority indicates the perceived parental potential to serve as an identification object or significant other.

In our view, the use of the term authority in this classification seems most appropriate with regard to the last two categories: expert and reference 
authority refer to a consolidated status that parents acquire for a certain practice over a certain time. For coercive authority and reward authority, which are more narrowly focused on specific situations, the term authority could be replaced by that of power. These two types refer to the perceived parental capacity to provide (negative and positive) sanctions as means of exerting influence; it is the parents' power to do this that is recognised, rather than their (stable) authority. The somewhat ambiguous use of the term authority becomes evident from the tautological notion of 'legitimate authority': parental authority is by definition legitimate if it is acknowledged by the child.

Despite the recognition of the importance of the child's perspective, this approach can be criticised for neglecting the dialogic dimension that parental authority can have. The importance of negotiation and reciprocity - in the sense of listening to each other and considering each other's positions - is not directly addressed. For instance, Peterson et al. (1985; Bush et al., 2004) actually distinguish between compliance as a more superficial form of following rules and the internalisation of parental values, beliefs and expectations. However, they do not discuss related behaviour and social actions of communication and negotiation. Rather than reconstructing the dynamics of parental authority, the discussion emphasises its 'outcome', presenting empirical evidence about effects such as the child's social competence (Henry, Wilson, \& Peterson, 1989; Peterson et al., 1999) or self-esteem (Bush et al., 2004; Peterson et al., 1985).

\section{Parental authority: a tentative conceptual proposition}

Our review of four contemporary approaches from developmental psychology discussing issues of parenting indicates that despite the general trend towards more democratic family relationships, especially in Western societies, the relevance of parental authority has not disappeared. In our concluding remarks, we seek to synthesise some of the key features of parental authority indicated in these approaches into a tentative conceptual proposition.

First of all, parental authority is a product of family communication that is constantly co-constructed in the process of interaction between parents and children in a given socioeconomic context. Unlike power, which is associated with one-sided and situative demonstrations of assertiveness, parental authority is relational and requires the active participation of the child in order to become a legitimate and institutionalised aspect of everyday family life.

Although parental power is ultimately rooted in public regulations of family relations, its micro-social relevance is established through its reproduction and ratification in the everyday practice of family life by both parents and 
children. Conceptually, parental power is little more than the promise inherent, for instance, in a trained muscle that can be activated. Parental authority, on the other hand, is more dynamic and refers to the shared family history. It is the joint product of a coordination process within the family, and it corresponds to common experiences that underline the mutual acknowledgement of each other's expectations, priorities and abilities to influence situations. While power is unilateral, authority requires mutuality.

Importantly, from the child's perspective, recognising authority does not automatically mean following it, and challenging authority - by testing limits, for example - does not mean denying it. The quality of parental authority always reflects the recognition of filial authority and the child's role in the formation of family relationships. In this way, the child's resistance to parental preferences is not understood as a threat to authority that needs to be overcome, but as a contribution to its ongoing development and revision. In order for parental authority to survive the early years of childhood dependence and into adolescence as a legitimate dimension of family relations, it needs to become part of the family routine of negotiating rules and contributions. The fact that the formally and legally subordinate party participates in the practice of parental authority indicates that parental authority refers to coagulated shared experience; it is the result of a process gradually consolidating out of the flow of family interactions. The social domains approach, in particular, emphasises the fact that features of social background and class translate differently into the way this internal dimension of legitimisation of parental authority is realised. Typical differences also exist with regard to parenting philosophies and approaches, or typical roles and behavioural patterns of parents and children.

Such a notion of parental authority is a key aspect of successful parenting, because education needs dialogue and a sense of each other's importance. At the same time, parental authority is not an end in itself. Ideally, its purpose is to increase the child's autonomy, which grows as authority matures and gradually fades into the background. Understood in this way, parental authority corresponds with contemporary parenting practices, as well as being closely connected with conceptual shifts in the communications and pedagogical literature. One example from communications literature is the widely recognised shift from the rather simplistic sender-receiver model towards a hermeneutic, relational, dialogic model of communication (e.g., Anderson, Baxter, \& Cissna, 2004). Similarly, in the pedagogical literature, the essentialist view of authority has been replaced by a relational one: while the former view tried to identify, for instance, the root of the teacher's authority (e.g., in his or her personality or greater intellectual or social power), the latter finds pedagogical authority 
in the interconnectedness of the educator, the child and the wider social circumstances (Bingham, 2006; Pace \& Hemmings, 2007; Harjunen, 2009, 2011; Kroflič, 2010).

Based on our review of selected developmental-psychological approaches, we suggest that parental authority is a complex, over-used and undertheorised concept. Although a tentative conceptualisation is possible, further conceptual work, and perhaps a review of additional approaches, is necessary in order to establish a general notion of parental authority. Against the background of our review, we believe that, in order to be useful for family, parenting and communication studies and to resolve conceptual contradictions and ambiguities, such a comprehensive concept of parental authority should not fall back behind the dimensions distinguished in the present study: its interactive co-construction and essentially relational character, its rootedness in everyday practice, and its internal and external legitimisation are key features for further theorising of parental authority, as well as for its empirical study.

Findings from research could be integrated into the revision and development of the concept, in turn improving its usefulness for research. A revised concept of parental authority would help to contextualise the significance of otherwise particularistic empirical findings for the assessment of the development of children and their relations with parents. Further research is also necessary to determine how to best use the concept. Such research could, for instance, indicate whether it could be measured explicitly in the sense of a construct, as Bush et al. (2004) suggest, as well as being used to differentiate collectivist and individualist countries, or to determine whether such a comprehensive concept of parental authority requires a fresh approach to research that involves new operationalisation.

In terms of practical work with families, a deeper understanding of the ambivalent facets and dynamics of parental authority would improve suitable forms of family counselling, prevention and therapy. Finally, the emphasis on mutually recognised authority, rather than one-sided power, in relationships between parents and children is transferable to other societal spheres where adults interact with young people. Further research needs to determine how dialogic competence rooted within the private sphere of the family could be addressed and further developed in the public sphere of schooling, or, in cases where it is lacking or underdeveloped, how its establishment could be facilitated. In the sense of self-evaluation, critical pedagogy will also ask how dialogic (or not) classroom authority of teachers is or should be in order to appropriately reflect trends towards democratisation within the family. 


\section{Acknowledgment}

The first author expresses special thanks to Prof. Robi Kroflič for all discussions on the topic of authority, and for his very useful comments and suggestions during the preparation of the present article.

\section{References}

Adorno, T., Frenkel-Brunswick, E., Levinson, D., \& Sanford, R. N. (1950). The authoritarian personality. New York: Harper.

Anderson, R., Baxter, L. A., \& Cissna, K. N. (Eds.) (2004). Dialogue: Theorizing difference in communication studies. Thousand Oaks, CA: Sage.

Ashbourne, L. M. (2009). Reconceptualizing parent-adolescent relationships: A dialogic model. Journal of Family Theory \& Review, 1(4), 211-222.

Barber, B. K. (1996). Parental psychological control: Revisiting a neglected construct. Child Development, 67, 3296-3319.

Barber, B. K., \& Harmon, E. L. (2002). Violating the self: Parental psychological control of children and adolescents. In B. K. Barber (Ed.), Intrusive parenting (pp. 15-52). Washington, DC: American Psychological Association.

Barber, B. K., Maughan, S. L., \& Olsen, J. A. (2005). Patterns of parenting across adolescence. In J. G. Smetana (Ed.), New directions for child and adolescent development, V. 108 - Changing boundaries of parental authority during adolescence (pp. 17-30). San Francisco: Jossey-Bass.

Baumrind, D. (1966). Effects of authoritative parental control on child behavior. Child Development, $37(4), 887-907$.

Baumrind, D. (1967). Child care practices anteceding three patterns of preschool behavior. Genetic Psychology Monographs, 75(1), 43-88.

Baumrind, D. (1971). Current patterns of parental authority. Developmental Psychology Monographs, 4, 1-102.

Baumrind, D. (1983). Rejoinder to Lewis' reinterpretation of parental firm control effects: Are authoritative families really harmonious? Psychological Bulletin, 94, 132-142.

Baumrind, D. (1989). Rearing competent children. In W. Damon (Ed.), Child development today and tomorrow (pp. 349-378). San Francisco: Jossey-Bass.

Baumrind, D. (1991). The influence of parenting style on adolescent competence and substance use. Journal of Early Adolescence, 11(1), 56-95.

Baumrind, D. (1996). The discipline controversy revisited. Family Relations, 45(4), 405-414.

Baumrind, D. (2005). Patterns of parental authority and adolescent autonomy. In J. G. Smetana (Ed.), New directions for child and adolescent development, V. 108 - Changing boundaries of parental authority during adolescence (pp. 61-69). San Francisco: Jossey-Bass.

Baumrind, D. (2012). Differentiating between confrontive and coercive kinds of parental power- 
assertive disciplinary practices. Human Development, 55, 35-51.

Baumrind, D., Larzelere, R. E., \& Owens, E. B. (2010). Effects of preschool parents' power assertive patterns and practices on adolescent development. Parenting: Science and Practice, 10, 157-201. Bingham, C. (2008). Authority is relational: Rethinking educational empowerment. New York: State University of New York Press.

Blood, R. O, \& Wolfe, D. M. (1960). Husbands and wives. Glencoe, IL: Free Press.

Bosma, H. A., Jackson, S. E., Zijsling, D. H., Zani, B., Cicognani, E., Xerri, M. L., Honess, T. M., \& Charman, L. (1996). Who has the final say? Decisions on adolescent behavior within the family. Journal of Adolescence, 19(3), 277-291.

Brannen, J., Dodd, K, Oakley, A., \& Storey, P. (1994). Young people, health and family life. Buckingham: Open University Press.

Buri, J. R. (1991). Parental authority questionnaire. Journal of Personality and Social Assessment, 57, 110-119.

Bush, K. R., Peterson, G. W., Cobas, J., \& Supple, A. J. (2002). Adolescents' perceptions of parental behaviors as predictors of adolescent self-esteem in mainland China. Sociological Inquiry, $72(4)$, 503-526.

Bush, K. R., Supple, A. J., \& Lash, S. B. (2004). Mexican adolescents' perceptions of parental behaviors and authority as predictors of their self-esteem and sense of familism. Marriage and Family Review, 36(1/2), 35-65.

Conger, K. J., Conger, R. D., \& Scaramella, L. V. (1997). Parents, siblings, psychological control, and adolescent adjustment. Journal of Adolescent Research, 12(1), 113-138.

Conger, R. D. (2009). Commentary on Grolnick and Pomerantz, Issues and challenges in studying parental control: Toward a new conceptualization. Child Development Perspectives, 3(3), 173-175.

Cromwell, R. E. \& Olson, D. H. (1975). Power in families. New York: Halstead Press.

Cumsille, P., Darling, N., Flaherty, B. P., \& Martinez, L. M. (2009). Heterogeneity and change in the patterning of adolescents' perceptions of the legitimacy: A latent transition model. Child development, $80(2), 418-432$.

Daddis, C., \& Smetana, J. (2005). Middle-class African American families' expectations for adolescents' behavioural autonomy. International Journal of Behavioral Development, 29, 371-381.

Darling, N., Cumsille, P., \& Martínez, M. L. (2007). Adolescents as active agents in the socialization process: Legitimacy of parental authority and obligation to obey as predictors of obedience. Journal of Adolescence, 30, 297-311.

Dornbusch, S. M., Ritter, P. L., Mont-Reynaud, R., \& Chen, Z.-y. (1990). Family decision-making and academic performance in a diverse high school population. Journal of Adolescent Research, 5(2), 142-16.

du Bois-Reymond, M., Büchner, P., \& Krüger, H. H. (1993). Modern family as everyday negotiation: Continuities and discontinuities in parent-child relationships. Childhood, 1(2), 87-99. du Bois-Reymond, M., te Poel, Y., \& Ravesloot, J. (1998). Jongeren en hun keuzes (Young people and their choices). Bussum: Coutinho. 
Dunbar, N. E. (2004). Dyadic Power Theory: Constructing a communication-based theory of relational power. Journal of Family Communication, 4, 235-248.

Florsheim, P., Tolan, P. H., \& Gorman-Smith, D. (1996). Family processes and risk for externalizing behavior problems among African American and Hispanic boys. Journal of Consulting \& Clinical Psychology, 64, 1222-1230.

French, J. R. P., \& Raven, B. (1959). The bases of social power. In D. Cartwright (Ed.), Studies in social power (pp. 150-167). Ann Arbor, MI: Institute for Social Research.

Galambos, N. L., Barker, E. T., \& Almeida, D. M. (2003). Parents do matter: Trajectories of change in externalizing and internalizing problems in early adolescence. Child Development, 74, 578-594.

Giddens, A. (1992). The transformation of intimacy: Sexuality, Love and Eroticism in Modern Societies. Stanford: Stanford University Press.

Gray, M. R., \& Steinberg, L. (1999). Unpacking authoritative parenting: Reassessing a multidimensional construct. Journal of Marriage and the Family, 61, 574-587.

Grolnick, W. S., \& Pomerantz, E. M. (2009). Issues and challenges in studying parental control: Toward a new conceptualization. Child Development Perspectives, 3(3), 165-170.

Grolnick, W. S. (2003). The psychology of parental control: How well-meant parenting backfires.

Hillsdale, NJ: Lawrence Erlbaum Associates.

Grolnick, W. S. (2009). The role of parents in facilitating autonomous self-regulation for education.

Theory and Research in Education, 7, 164-173.

Grusec, J. E. (2009). Commentary on the proposed abandonment of multiple forms of control. Child Development Perspectives, $3(3), 171-172$.

Hallenbeck, P. N. (1996). An analysis of power dynamics in marriage. Journal of Marriage and the Family, 28, 200-203.

Harjunen, E. (2009). How do teachers view their own pedagogical authority? Teachers and teaching: Theory and practice, 15(1), 1470-1478.

Harjunen, E. (2011). Students' consent to a teacher's pedagogical authority. Scandinavian Journal of Educational Research, 55(4), 403-424.

Henry, C. L., Wilson, L. M., \& Peterson, G. W. (1989). Parental power bases and processes as predictors of adolescent conformity. Journal of Adolescent Research, 4, 15-32.

Hoffman, M. L. (1970). Moral development. In P. H. Mussen (Ed.), Carmichael's manual of child psychology (Vol. 2, pp. 457-557). New York: Wiley.

Hoffman, M. L. (1983). Affective and cognitive processes in moral internalization: An information processing approach. In E. T. Higgins, D. Ruble, \& W. Hartup (Eds.), Social cognition and social development: A sociocultural perspective (pp. 236-274). New York: Cambridge University Press. Kroflič, R. (1997). Avtoriteta v vzgoji (Authority in education). Ljubljana: ZPS.

Kroflič, R. (2010). Dialoški model avtoritete kot spopad za vzajemno pripoznanje: feministična kritika lacanovskega pogleda na avtoriteto [The dialogic model of authority as a struggle for mutual recognition: Feminist criticism of Lacan's view of authority]. Sodobna pedagogika [Contemporary pedagogics], 61(3), 134-154. 
Lamborn, S., \& Felbab, A. (2003). Applying ethnic equivalence and cultural values models to African American teens' perceptions of parents. Journal of Adolescence, 26, 605-622.

Lewin, K., Lippitt, R., \& White, R. K. (1939). Patterns of aggressive behavior in experimentally created social climates. Journal of Social Psychology, 10, 271-301.

Maccoby, E. E., \& Martin, J. A. (1983). Socialization in the context of the family: Parent-child interaction. In P. H. Mussen (Ed.) \& E. M. Hetherington (Vol. Ed.), Handbook of child psychology:

Vol. 4. Socialization, personality, and social development (pp. 1-101). New York: Wiley.

Maccoby, E. E. (2007). Historical overview of socialization research and theory. In J. E. Grusec \&

P. D. Hastings (Eds.), Handbook of socialization: Theory and research (pp. 13-41). New York, NY:

Guilford Press.

Mandara, J. (2003). The typological approach in child and family psychology: A review of theory, methods, and research. Clinical Child \& Family Psychology Review, 6, 129-146.

Mason, C. A., Cauce, A. M., Gonzales, N., \& Hiraga, Y. (1996). Neither too sweet nor too sour: Antisocial peers, maternal control, and problem behavior in African American adolescents. Child Development, 67(5), 2115-2130.

Nucci, L. (2001). Education in the Moral Domain. Cambridge: Cambridge University Press. Nucci, L., \& Smetana, J. G. (1996). Mothers' conceptions of young children's areas of personal freedom. Child Development, 67, 1870-1886.

Pace, J. L., \& Hemmings, A. (2007). Understanding authority in classrooms: a review of theory, ideology, and research. Review of educational research, 77(1), 4-27.

Perelberg, R. J. (1990). Equality, asymmetry, and diversity: On conceptualisations of gender. In R. J. Perelberg \& A. Miller (Eds.), Gender and Power in Families (pp. 34-62). London: Routledge. Peterson, G. W. (1986). Family conceptual frameworks and adolescent development. In G. K. Leigh \& G. W. Peterson (Eds.), Adolescents in families (pp. 12-35). Cincinnati, OH: Southwestern Publishing Co.

Peterson, G. W., \& Hann, D. (1999). Socializing children and parents in families. In M. B. Sussman, S. K. Steinmetz, \& G. W. Peterson (Eds.), Handbook of marriage and the family (pp. 327-370). New York: Plenum Press.

Peterson, G. W., Bush, K. F., Wilson, S. M., \& Hennon, C. B. (2005). Family relationship predictors of parent-adolescent conflict: Cross-cultural similarities and differences. International Family Strengths Consortium, Cuernavaca, Mexico. Retrieved July 32008 from http://www.ciesas.edu.mx/proyectos/ mifs2005/papers/o4/peterson_bush_wilson_hennon.pdf Peterson, G. W., Bush, K. R., \& Supple, A. J. (1999). Predicting adolescent autonomy from parents: Relationship connectedness and restrictiveness. Sociological Inquiry, 69, 431-57. Peterson, G. W., Rollins, B. C., \& Thomas, D. L. (1985). Parental influence and adolescent conformity: Compliance and internalization. Youth and Society, 16, 297-420.

Peterson, G. W., Steinmetz, S. K., \& Wilson, S. M. (Eds.) (2005). Parent-youth relations: Cultural and cross-cultural perspectives. New York, NY, US: Haworth Press.

Pomerantz, E. M., \& Grolnick, W. S. (2009). Toward a clear and inclusive conceptualization of 
parental control: Response to the commentaries. Child Development Perspectives, 3(3), 176-177. Rollins, B. C., \& Bahr, S. J. (1976). A theory of power relationships in marriage. Journal of Marriage and the Family, 38, 619-627.

Safilios-Rothschild, C. (1970). The Study of Family Power Structure: A Review 1960-1969. Journal of Marriage and the Family, 31(4), 290-301.

Scanzoni, J. (1979). Social processes and power in families. In W. Burr, R. Hill, F. Nye, \& I. Reiss (Eds.), Contemporary Theories about the Family (Vol. 1, pp. 295-316). New York: The Free Press. Schaefer, E. S. (1965). Children's report of parental behavior: An inventory. Child Development, 36 , 413-424.

Schneewind, K. A. (1999). Familienpsychologie. Stuttgart: Kohlhammer.

Smetana, J. G., \& Chuang, S. (2001). Middle class African American parents' conceptions of parenting in early adolescence. Journal of Research on Adolescence, 11, 177-198.

Smetana, J. G. (1988). Adolescents' and parents' conceptions of parental authority. Child Development, 59, 321-335.

Smetana, J. G. (1989). Adolescents' and parents' reasoning about actual family conflict. Child Development, 6o, 1052-1067.

Smetana, J. G. (1995). Parenting styles and conceptions of parental authority during adolescence.

Child Development, 66, 299-316.

Smetana, J. G. (2011). Adolescents, families, and social development: How adolescents construct their worlds. West Sussex, England: Wiley-Blackwell, Inc.

Smetana, J. G., Crean, H. F., \& Campione-Barr, N. V. (2005). In J. G. Smetana (Ed.), New directions for child and adolescent development, V. 108 - Changing boundaries of parental authority during adolescence (pp. 31-46). San Francisco: Jossey-Bass.

Smetana, J. G., Killen, M., \& Turiel, E. (1991). Children's reasoning about interpersonal and moral conflicts. Child Development, 62, 629-644.

Smetana, J. G., Metzger, A., Gettman, D., \& Campione-Barr, N. (2006). Disclosure and secrecy in adolescent-parent relationships. Child Development, 77, 201-217.

Soenens, B., \& Beyers, W. (2012). The cross-cultural significance of control and autonomy in parentadolescent relationships. Journal of Adolescence, 35, 243-248.

Solomon, Y., Warin, J., Langford, W., \& Lewis, C. (2002). Intimate talk between parents and their teenage children: democratic openness or covert control? Sociology, 36(4), 965-983.

Sorkhabi, N. (2005). Applicability of Baumrind's parent typology to collective cultures: Analysis of cultural explanations of parent socialization effects. International Journal of Behavioral Development, $29(6), 552-563$.

Stattin, H., \& Kerr, M. (200o). Parental monitoring: A reinterpretation. Child Development, 71(4), $1072-1085$.

Steinberg, L. (1990). Autonomy, conflict, and harmony in the family relationship. In S. Feldman \& G. Elliot (Eds.), At the threshold: The developing adolescent (pp. 255-276). Cambridge, MA: Harvard University Press. 
Steinberg, L. (2005). Psychological control: Style or substance? In J. G. Smetana (Ed.), New directions for child and adolescent development, V. 108 - Changing boundaries of parental authority during adolescence (pp. 71-78). San Francisco: Jossey-Bass.

Steinberg, L., Dornbusch, S. M., \& Brown, B. B. (1992). Ethnic differences in adolescent achievement: An ecological perspective. American Psychologist, 47, 723-729.

Steinberg, L., Lamborn, S., Darling, N., Mounts, N., \& Dornbusch, S. M. (1994). Over-time changes in adjustment and competence among adolescents from authoritative, authoritarian, indulgent, and neglectful families. Child Development, 65, 754-770.

Steinberg, L., Mounts, N. S., Lamborn, S. D., \& Dornbusch, S. M. (1991). Authoritative parenting and adolescent adjustment across varied ecological niches. Journal of Research on Adolescence, 1, 19-36. Ule, M. (1977). Socialno-psihološki vidiki avtoritete [Socio-psychological aspects of authority]. Anthropos, (5/6), 69-89.

Yau, J. Y., Tasopoulos-Chan, M., \& Smetana, J. G. (2009). Disclosure to parents about everyday activities among American adolescents from Mexican, Chinese, and European backgrounds. Child Development, 80, 1481-1498.

Yau, J., \& Smetana, J. G. (1996). Adolescents-parent conflict among Chinese adolescents in Hong Kong. Child Development, 67, 1262-1275.

Zambrano, E. (2001). Authority, Social theories of. In N. J. Smelser \& P. B. Baltes (Eds.), International Encyclopedia of Social \& Behavioral Sciences (pp. 978-982). Oxford: Elsevier.

\section{Biographical note}

Metka Kuhar, Ph.D., Associate Professor, is a researcher and teaching professor at the University of Ljubljana, Faculty of Social Sciences. Her areas of research expertise are transitions to adulthood and family life, youth participation and interpersonal communication. She has been cooperating with the Council of Europe in the field of youth studies and youth policies and has been involved in many domestic and certain international projects on young people (e.g. Up2youth).

Herwig Reiter, Ph.D., Senior Researcher, holds a PhD in Political and Social Sciences from the European University Institute and currently works as senior researcher at the German Youth Institute in the Department of Social Monitoring and Methodology. His main areas of work include youth and youth policy in Europe, work and unemployment, life course and biography, transformation research, and qualitative methods. 